Adam M. FILIPOWICZ

IF WFCh UKSW

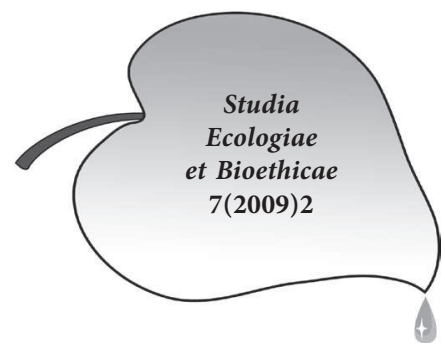

\title{
Zagadnienie zła $w$ polemice Tertuliana z Gnozą
}

\section{Słowo wprowadzenia}

Człowiek od wieków zadawał sobie pytania na temat pochodzenia zła, jego natury i własnej za nie odpowiedzialności. W Księdze Rodzaju czytamy, że: Bóg widział, że wszystko, co uczynit, było bardzo dobre'. Można przypomnieć przypowieść Chrystusa o chwaście ze słynnym pytaniem: Panie, czy nie posiałeś dobrego nasienia na swej roli? Skąd więc wzią się na niej chwast?2. Na przestrzeni dziejów ludzie proponowali różne wyjaśnienia. Na płaszczyźnie metafizyczno-ontologicznej, w myśli greckiej zjawisko zła wyjaśniano odwołując się do zasady materialnej, ale nie sprowadzano tego do formy i czystego aktu; na późną myśl helleńską oddziaływała dualistyczna koncepcja istnienia zła i dobra pochodzenia orientalnego; w neoplatonizmie sformułowana została koncepcja zła jako braku dobra ${ }^{3}$. Nurty gnostyckie, które w pierwszych wiekach rodzącego się chrześcijaństwa, stanowiły dla niego poważne wewnętrzne zagrożenie od strony doktrynalnej, przerzucały odpowiedzialność i winę za zło na samego Boga. W niniejszym opracowaniu podjęto zagadnienie zła w kontekście polemiki, jaką prowadził Tertulian, słynny chrześcijański apologeta z przełomu II i III wieku z mnożącymi się herezjami. Rozważania opierać się będą zasadniczo na analizie wybranych pism apologetycznych i dogmatyczno-polemicznych omawianego Autora, takich jak:

Rdz 1, 31; skróty ksiąg Pisma św. według Biblii Tysiąclecia: Pismo Święte Starego i Nowego Testamentu w przekładzie z języków oryginalnych, oprac. zespół biblistów polskich z inicjatywy Benedyktynów Tynieckich, Poznań - Warszawa 1989.

2 Mt 13, 27.

3 Por. hasło: Zło, w: G. ReAle, Historia filozofii starożytnej, t. V, Lublin 2002, s. 264. 
Adversus Hermogenem ${ }^{4}$, Adversus Valentinianos ${ }^{5}$, Adversus Martionem ${ }^{6}$, Apologeticum ${ }^{7}$, De anima .

\section{Pochodzenie zla}

Zagadnienie zła obejmuje szereg płaszczyzn. Na płaszczyźnie filozoficznej może oznaczać wybór dobra niższego kosztem dobra wyższego, ale rozpatrywane w sferze moralnej, rozumiane jako grzech i wada, traktowane bywało przez Greków jako błąd rozumu i fałszywe mniemanie9. Na płaszczyźnie religijnej zło jawiło się jako przekroczenie Bożych przykazań ${ }^{10}$. Każde z tych stanowisk można sprowadzić do podstawowego pytania, skąd się zło bierze, jaki jest jego początek i pochodzenie.

W pierwszych wiekach myśl chrześcijańska była poddana silnym wpływom pogaństwa i myśli gnostyckiej. W Rzymie od 139 roku działał, pochodzący z Synopy nad Morzem Martwym, Marcjon. Był on twórcą sekty, której poglądy polegały na synkretyzmie pogaństwa $\mathrm{z}$ chrześcijaństwem ${ }^{11}$. Marcjon uznawał dualizm, głosił, że istnieje dwóch Bogów. Bóg Starego Testamentu, Stwórca, jest surowy i zły i w nim znajduje się przyczyna i źródło zła. Jemu Marcjon przeciwstawiał Boga Nowego Testamentu, Boga pełnego dobroci i łagodności ${ }^{12}$. Z kolei pochodzący z Kartaginy malarz Hermogenes w swoich doktrynach mieszał elementy gnostyckie, platońskie i chrześcijańskie. Uczył, że Bóg stworzył świat z odwiecznie istniejącej materii i ona, jako zła, jest przyczyną zła istniejącego na świecie. Do grona gnostyków zalicza się też pochodzącego z Egiptu Walentyna. Po gruntownych studiach w Aleksandrii udał się on do Rzymu, gdzie zabiegał

4 Wydania: Patrologiae Cursus Completus. Series Latina (PL), ed. J.-P. Migne, Paris 1844-1855: PL 2, 195-238; Corpus Scriptorum Ecclesiasticorum Latinorum (CSEL), Wien 1866-: CSEL 46, s. 126-176; Corpus Christianorum. Series Latina (CCL), Turnholti 1954: CCL 1, s. 395-435.

5 Wydania: PL 2, s. 523 (569) n, CSEL 47, s. 177-212, CCL 2, s. 751-778; A. MArastoni, Roma 1971; J.-C. FredoulLLe, Paris 1980-1981.

6 Wydania: PL. 2, s. 239 (263) n.; CSEL 47, s. 290-650; CCL 1, s. 437-726; C. MoresChini, Milano 1971; E. Evans, Oxford 1972, t. 1-2; R. Braun, Livre I, Paris 1990, Livre II Paris 1991. Tłum. pol.: Tertulian, Przeciw Marcjonowi, Przekład: o. S. Ryzner; Wstęp i Opracowanie: Ks. W. Myszor, Pisma Starochrześcijańskich Pisarzy (PSP) 58, Warszawa 1994.

7 Wydania: PL 1, s. 257 (305) nn.: CSEL 69, CCL 1, s. 77-171. Tłum. pol.: Tertulian, Apologetyk, tłum., wstęp i objaśnienia J. Sajdak, Pisma Ojców Kościoła (POK) 20, Poznań 1947.

8 Wydania: PL 2, 641-752; CCL 2, s. 779-869. Tłum. polskie, fragmenty: M. Michalski, Antologia literatury patrystycznej, Warszawa 1975, t. 1, s. 233-242.

9 Por. hasło: Zło, w: G. Reale, Historia filozofii..., dz.cyt., t. V, s. 264-265.

10 Por. hasło: Grzech, w: G. Reale, Historia filozofii..., dz.cyt., t. V, s. 87-88.

11 Por. M. СутоwsкA - H. Szelest, Literatura rzymska. Okres cesarstwa - autorzy chrześcijańscy, Warszawa 1994, s. 40.

12 Por. Adversus Marcionem I, 6: Marcionem disparos deos constituere: alterum iuduicem, ferum, belli potentem, alterum mitem, placidum et tantummodobonum atque optimum. 
o godność biskupa. Nie osiągnąwszy tego celu, przyłączył się do sekty gnostyków tworząc własną szkołę. Powołując się na cytaty z Ewangelii uzasadniał gnostycki dualizm. Uczył, że wszystkie byty na drodze emanacji i przemian pochodzą z absolutu, a obok świata dobrego i idealnego istnieje świat zła, stąd też panuje ciągła walka dobra ze złem ${ }^{13}$.

Podejmując polemikę z heretykami, Tertulian ostro krytykuje ich poglądy i wytyka głupotę, skoro uważają, że inny jest Bóg Dobry i inny ten, który jako Stwórca jest też sprawcą zła, bądź też materię zestawiają ze Stwórcą, aby z niej wyprowadzać zło i nie obciążać nim Stwórcy ${ }^{14}$. Tertulian wykazuje, że gdyby Bóg faktycznie stworzył świat z odwiecznej materii, o której wiedział, że była zła, to albo sam był słaby, skoro wcześniej jej nie naprawił, albo mogąc ją wcześniej naprawić, nie chciał tego uczynić, wobec czego jest winny istniejącego zła. Rozumowanie takie prowadzi jednak do absurdu, gdyż Bóg działałby sam przeciw sobie nie akceptując zła i jednocześnie powołując do istnienia to, o czym wiedział, że będzie złe ${ }^{15}$. Podobnie dopuszczając zło w miejsce dobra, Bóg byłby jego rzecznikiem. Dalej Tertulian udowadnia, że zło nie mogłoby przynależeć odwiecznej materii, gdyż to co wieczne, nie mogłoby być podporządkowane i podległe innemu wiecznemu bytowi jakim jest Bóg. Nawet gdyby uznać materię za wieczną, ta nie mogłaby zawierać zła, gdyż to co wieczne, musi być najwyższym dobrem. Przyjmując natomiast, że coś wiecznego może mieścić w sobie zło, to tak samo należałoby przypisać je wiecznemu Bogu, czego Hermogenes jednak nie dopuszczał ${ }^{16}$. Tertulian wykazuje także, że zgodnie z poglądami

13 Por. M. CyтowsKa - H. Szelest, Literatura rzymska ..., dz. cyt., s. 41.

14 Por. Adversus Hermogenem, X, 1: Magna, bona fide, caecitas haereticorum pro huiusmodi argumentatione, cum ideo aut alium deum bonum et optimum uolunt credi quia mali auctorem existiment creatorem aut materiam cum creatore proponunt, $u t<m>$ al [i] um a materia, non a creatore deducant, quando nullus omnino deus liberetur ista quaestione, utnonauctor mali uideri proinde possit quisquis ille est qui malum, etsi non ipse fecit, tamen a quocumque et undeunde passus est fieri.

15 Por. tamże, X, 2-3: Ecce enim, etsi non auctor, sed assentator mali inuenitur deus qui malum materiae tanto sustinuit de bono ante mundi constitutionem quam ut bonus et mali aemulus emendasse debuerat. [3] Aut enim potuit emendare sed noluit aut uoluit quidem uero non potuit infirmus deus. Si potuit et noluit, malus et ipse, quia malo fauit, et sic iam habetur eius quod, licet non instituerit, qui<a> tamen, si noluisset illud esse, non esset, ipse iam fecit esse quod noluit non esse. Quo quid est turpius? Si id uoluit esse quod ipse noluit fecisse, aduersum semetipsum egit, cum et uoluit esse quod noluit fecisse et noluit fecisse quod uoluit esse. Quasi bonum uoluit esse et quasi malum noluit fecisse; quod non faciendo malum iudicauit, id sustinendo bonum pronuntiauit. Malum pro bono sustinendo et non potius eradicando assertor eius inuentus est, male, si per uoluntatem, turpiter, si per necessitatem. Aut famulus erit mali deus aut amicus, cum materiae malo conuersatus, nedum etiam de malo eius operatus.

16 Por. tamże, XI, 1: Nam definimus diminutionem et subiectionem capere non posse quod si<t> aeternum, ut alii coaeterno inferius deputetur. Ita et nunc nec malum dicimus competere illi, quia nec ex hoc subici possit, quod nullo modo potest subici, quia aeternum est. Sed cum alias summum 
Hermogenesa, materia jako wieczna, nieuczyniona i niezrodzona, powinna być zarazem niezmienna i niezniszczalna. Zakładając, że materia jest zła także co do natury, prowadzi to do kolejnych sprzeczności w rozumowaniu, gdyż Bóg stworzył dobre rzeczy i jako dobre je pobłogosławił ${ }^{17}$. Należałoby zatem uznać, że materia dopuściła zmianę, ta, która jako wieczna zmienną być nie mogła. Tertulian stawia tu zatem kolejne pytanie o pochodzenie dobra, skoro materia była złą i nie dopuszczała zmiany: Skad w tym, co złe, a nawet bardzo złe, nasienie dobrego $i$ bardzo dobrego? Wszak dobre drzewo nie wydaje złych owoców, bo i nie ma innego Boga, jak tylko Dobrego, ani złe drzewo dobrych, bo i materia inna nie istnieje, jak tylko bardzo $z \nmid a .^{18}$

Jedyna możliwość w takiej sytuacji, to przyjąć, że materia miała podwójną naturę obfitującą zarówno w dobro i zło, ale wówczas, gdyby Bóg faktycznie stwarzał świat $\mathrm{z}$ odwiecznej materii, pozostawałby jej sługą i niczego nie dokonałby $\mathrm{z}$ własnego geniuszu. $\mathrm{W}$ takiej sytuacji, stwierdza Tertulian, nie powinniśmy Bogu ani dziękować za dobro, ani też okazywać nienawiści za zło ${ }^{19}$.

Tertulian mocno podkreśla w swoich pismach, że nie należy Boga oskarżać za zło, gdyż jest ono wynikiem sprzeniewierzenia się woli Bożej i niewłaściwego korzystania z Bożych darów wolności i wolnej woli. W przypadku człowieka wolna wola jest władzą i sprawnością duszy ${ }^{20}$. To nie Bóg jest zatem winien zła, które czyni człowiek. Tertulian przekonuje o błędności poglądów zwolenników Marcjona, walentynian i wykazuje, że dar wolnej woli rodzi osobistą odpowiedzialność każdego za dobro i zło ${ }^{21}$ : A więc cała wolność wyboru udzielona mu została na obydwie strony, aby się okazywat stale panem samego siebie tak w ochotnym zachowaniu dobra, jak i $w$ dobrowolnym unikaniu zła. Bo i $z$ innej strony wypadało, aby człowiek postawiony na sadzie Boskim okazał się sprawiedliwym na mocy zasług swojej woli, oczywiście wolnej ${ }^{22}$.

bonum constet esse quod sit aeternum ut deus, per quod solus est deus, dum aeternus est, et ita bonus, dum deus, quomodo materiae inerit malum, quam ut aeternam summum bonum credi necesse est?.

17 Por. tamże, XII, 1-4.

18 Tamże, XIII, 1: Unde in mala ac pessima boni atque optimi semen? Certe nec bona arbor fructus malos edit, quia nec deus nisi bonus, nec mala arbor bonos, quia nec materia est <nisi $>$ pessima.

19 Por. tamże, XIII, 3: Aut si potuit utriusque diuersitas, boni et mali, concurrisse et duplex natura fuisse materiae, amborum ferax fructuum, iam nec bona ipsa deo deputabuntur, ut nec mala illi inputentur, sed utraque species de materiae proprietate sumpta ad materiam pertinebit. Quo pacto neque gratiam bonorum deo debebimus nec inuidiam malorum, quia nihil de suo operatus ingenio; per quod probabitur manifeste materiae deseruisse.

20 Por. Adversus Marcionem II, 5, 6: bo ona (dusza) zapewnia mu wolność jego sądu i możność wyboru. (tłum. PSP 58, s. 74).

21 Por. M. Menghi, La corporietà dell'anima e l'innocenza della carne, w: Tertulliano, Ĺanima, a cura di M. Menghi, Venezia 1988, s. 25.

22 Adversus Marcionem II, 6, 6: Tota ergo libertas arbitrii in utramque partem concessa est illi, ut sui dominus constanter occurreret et bono servando et malo sponte vitando, quoniam et alias positum 


\section{Wolna wola a wybór pomiędzy dobrem i złem}

Jest oczywiste, że każdy człowiek czegoś w życiu chce, czegoś pragnie, za czymś podąża. W ślad za poznaniem zmysłowym i rozumowym może powstać pragnienie zdobycia lub odrzucenia tego, co się poznało. Może zrodzić się decyzja do dążenia i działania w celu zdobycia lub uniknięcia określonych i poznanych wcześniej np. przedmiotów czy wydarzeń. W tym chceniu i działaniu człowiek jest wolny $i$ to wola jest bezpośrednią przyczyną chcenia i działania. Jest ona zatem zdolnością do świadomego chcenia, wolnego wyboru, podejmowania i realizacji decyzji oraz zadań, do panowania nad sobą, czy też do świadomej miłości lub nienawiści, albo np. cierpienia ${ }^{23}$.

Wśród władz intelektualnych człowieka istotna jest zatem wolna wola, ale nie wszystkie systemy filozoficzne ją uznawały. W starożytnej refleksji filozoficznej wolność człowieka rozpatrywano początkowo szczególnie w aspekcie społecznopolitycznym, który bardzo fascynował wszystkich wielkich myślicieli, pragnących zbudować silne racjonalne podstawy państwa i społeczeństwa ${ }^{24}$. Później wraz z pojawieniem się cynizmu i stoicyzmu, akcent został przesunięty na wewnętrzny wymiar wolności człowieka, z podkreśleniem jej aspektu duchowego, który mógł się przekładać na zewnętrzne działania, ale przede wszystkim jawił się jako podstawowy dla całościowego spojrzenia na fenomen wolności osoby ludzkiej ${ }^{25}$. Dla Greków jednak wola była ściśle związana z rozumem, była nie tyle autonomiczną funkcją duszy, co dążeniem do celu (lub przedmiotu) bardziej lub mniej znanego czy wyobrażonego. Starożytnym Grekom chodziło więc raczej o wolność decyzji, a Rzymianie wprowadzili termin liberum arbitrium ${ }^{26}$. Stoicyzm, który wywarł duży wpływ na myśl Tertuliana, ukazywał człowieka wolnego, który ma możliwość dysponowania samym sobą niezależnie od woli kogokolwiek i wpływu jakichkolwiek czynników wewnętrznych i zewnętrznych, który żyje zgodnie $\mathrm{z}$ naturą oraz potrafi panować nad nieuporządkowanymi odruchami swego ducha i ciała. Ta wewnętrzna wolność osobista człowieka, mogąca rzutować na jego

hominem sub iudicio Dei oportebat iustum illud efficere de arbitrii sui meritis, liberi scilicet. (tłum. PSP 58, s. 76).

23 Por. G. Dogiel, Antropologia filozoficzna, dz. cyt., s. 37; J. Galarowicz, Na ścieżkach prawdy. Wprowadzenie do filozofii, Kraków 1992, s. 542.

24 Por. O. Gigon, Der Begriff der Freiheit in der Antike, „Gymnasium” 80 (1973), s. 8-56; V. FoÀ Guazzoni, La libertà nel mondo greco, 1-2, Genova 1972-1974; A.J. Festugière, Liberté et civilisation chez les Grecs, Paris 1947; D. Amand, Fatalisme et liberté dans l'antiquité grecque, Louvain 1945; A. Momigliano, La libertà di parola nel mondo antico, „Rivista Storica Italiana” 83 (1971), s. 499-524; S. STRĘKOWsкI, De apologeticis argumentis religiosae libertatis apud Tertullianum. Thesis ad Doctoratum, Roma 1995.

25 Por. S. StręKowsкi, Wolność osobista człowieka według Tertuliana, „Studia Teologiczne” (ST) 14 (1996), s. 175.

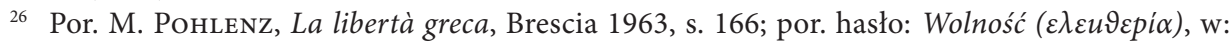
G. REALE, Historia filozofii starożytnej, dz. cyt., t. V, s. 255-257. 
wolność zewnętrzną i zachowania, stawała się wyrazem działającej w człowieku władzy wolnej woli. Wprawdzie wola u Seneki, który mówi o voluntas i velle, otrzymuje nowe znaczenie ${ }^{27}$, ale - jak zaznacza G. Reale - nie jest ono do końca adekwatnie uzasadnione ${ }^{28}$. Również proaíresis Epikteta ma charakter bardziej intelektualistyczny niż woluntarystyczny ${ }^{29}$. Według niektórych badaczy funkcję decydującą woli miał przypisać Porfiriusz, wyprzedzając w tym stanowisko Augustyna. Taka interpretacja jednak zdaniem Realego nie ma potwierdzenia $\mathrm{w}$ tekstach ${ }^{30}$. Można ją natomiast odnaleźć u Filona Aleksandryjskiego ${ }^{31}$, który $\mathrm{w}$ tej materii wykorzystuje kategorie zaczerpnięte raczej z Biblii, aniżeli od greckich filozofów ${ }^{32}$.

Gnostycy odrzucali wolność woli człowieka. Takie stanowisko mogło prowadzić jednak do zakwestionowania odpowiedzialności człowieka za jego czyny, słuszności dokonywania osądów, wyznaczania nagród i kar, a ciężar winy przenosiłoby nawet na samego Boga ${ }^{33}$. Tertulian w polemice $\mathrm{z}$ heretykami nigdy nie kwestionował aspektu wolitywnego w człowieku i podkreślał zdolność duszy do

\footnotetext{
27 Seneka wolność osobistą człowieka definiował następująco: Quae sit libertas quaeris? Nulli rei servire, nulli necessitati, nullis casibus, fortunam in aequum deducere.- Pytasz, co to jest wolność? Nie być niewolnikiem żadnej rzeczy, żadnej potrzeby, żadnych wydarzeń, przymusić swój los do równego postępowania z sobą, zob.: Epistulae, 51, 9, w: SENEKA, Ad Lucilium Epistulae Morales, with an English translation by R.M. Gummere, vol. 1-3, Cambridge - Massachusetts - London 1962-1967; SENEKA, Listy moralne do Lucyliusza, tłum. W. Kornatowski, Warszawa 1998 dz. cyt., s. 193; nemo liber qui corpori servit - Nikt z tych, co służa ciału, nie jest wolny, w: Epistulae, 92, 33, dz. cyt., s. 454.

28 Por. G. Reale, Historia filozofii, dz. cyt., t. IV, s. 112 n.; t. V, s. 254.

29 Por.tamże, t. IV, s. 137 n.

30 Por. TAMŻE, s. 631, przyp. 22.

31 Por. TAMŻE, t. IV, s. 317 n.

32 Znaczenie pojęcia «wolność» w kontekście starożytności pogańskiej najlepiej według Realego przedstawił M. Pohlenz: Słowo «wola» ma dla Hellenów inne i o wiele bardziej zawężone znaczenie aniżeli dla nas, tak że nie tylko u Sokratesa, lecz także w całej filozofii greckiej schodzi ono absolutnie na plan drugi, bez względu na to, jak bardzo skłonni byliby wspótcześni historycy filozofii przenosić do myśli greckiej swoją własna koncepcję woli i odnajdywać ją w thymós Platona, albo w „wyborze” Arystotelesa, albo gdziekolwiek indziej. Kiedy my mówimy „wola”, wówczas mamy na myśli [...] funkcje psychiczna różna zarówno od rozumu, jak i od uczucia, i odbieramy ją także jako coś niezależnego od przedmiotu, do którego się zwraca. Mówimy np. o „sile woli” czy o „człowieku o silnej woli”, nie podajac żadnej informacji o ukierunkowaniu tej woli. Takiego wyrażenia absolutnie nie da się przełożyć na język grecki, można je co najwyżej sparafrazować tak: „jest to ktoś, kto mocno chce tego, czego chce”. Zakłada to, że Grek zna tylko i wyłacznie chcenie, które kieruje się do jakiegoś celu bardziej lub mniej poznanego i dostrzeżonego: do konkretnego przedmiotu lub określonego działania. [...] Umysłowość grecka nie czuje potrzeby przyjmowania jakiegoś szczególnego chcenia, niezależnego od poznania; z samego bowiem przedstawienia tego co pożyteczne lub dobre i z wizji wytkniętego celu wypływa wola działania., w: G. ReAle, Historia filozofii, dz. cyt., t. IV, s. 317; cyt. za: G. ReALe, Historia filozofii, dz. cyt., t. V, s. 254.

33 Por. J. Alexandre, Une Chair Pour La Gloire. Lanthropologie faliste et mystique de Tertullien, Paris 2001, dz. cyt., s. 165-172.
} 
wolnego osądu i wyboru. Szczególnie dał temu wyraz w Adversus Marcionem II, 5-9. Wolność woli, według Kartagińczyka, należy do naturalnych władz du$\mathrm{szy}^{34} \mathrm{i}$ jest jednym z czynników warunkujących Boże podobieństwo w człowieku: Widzę, że Bóg stworzyt człowieka wolnym $i w$ jego sądzie, $i w$ woli, $i w$ możności wyboru, a nie spostrzegam żadnego innego podobieństwa do Boga i Jego obrazu jak właśnie ten stan i tę formę ${ }^{35}$.

Wolna wola zdaniem Tertuliana warunkuje nie tylko Boże podobieństwo, ale także godność człowieka i jego wyższość nad światem, przez fakt uzyskania władzy nad sobą: Wypadało przeto, by obraz i podobieństwo Boga było obdarzone wolna wola i możnością swego wyboru, na której to wolności i możności sam przez się obraz i podobieństwo do Boga zasadza. A do tego sama istota człowieka jest przystosowana, aby byt takiego stanu, mianowicie wolny w wyborze i władzy nad sobą, dzięki tchnieniu Boga. Inaczej bowiem jakżeby to wygladało, aby człowiek posiadajacy władze nad całym światem nie miał najpierw władzy nad swoim rozumem i nie królował nad nim on jako pan nad innymi, sługa samego siebie?36.

Tertulian zaznacza, że człowiek z ustanowienia Bożego jest nastawiony na dobro, ale zarazem ma wolną wolę i może dokonywać wyboru, tak aby nie być niewolnikiem i sługą dobra. Tym większa zatem także zasługa człowieka, kiedy dobrowolnie wybiera dobro, bez żadnego przymusu i determinacji. Już samo dobro zasługuje na to, by podejmować je z ochotą i z własnej woli. Możność dokonywania wyboru i wolna wola stwarzają szanse na rozwój człowieka i doskonalenie, między innymi poprzez przeciwstawianie się złu i panowanie nad sobą. Człowiek gdyby był pozbawiony tego prawa i dobro czynił nie z własnej woli, ale z konieczności, zło uzurpowałoby sobie w przyszłości władzę nad nim, na skutek jego słabości. Wobec tego zarówno w czynieniu zła, jak i dobra człowiek byłby sługą ${ }^{37}$.

34 Por. De anima 21, 6.

35 Adversus Marcionem II, 5, 5: Liberum et sui arbitrii et suae potestatis invenio hominem a Deo institutum, nullam magis imaginem et similitudinem Dei in illo animadvertens quam eiusmodi status formam (tłum. PSP 58, s. 74).

36 TAмże, II, 6, 3: Oportebat igitur imaginem et similitudinem Dei liberi arbitrii et suae potestatis institui, in qua hoc ipsum imago et similitudo Dei reputaretur, arbitrii scilicet libertas et potestas. In quam rem ea substantia homini accommodata est, quae huius status esset, adflatus Dei, utique liberi et suae potestatis. Sed et alias quale erat, ut totius mundi possidens homo non inprimis animi sui possessione regnaret, aliorum dominus sui famulus? (tłum. PSP 58, s. 74-75).

37 Por. TAMżE, II, 6, 5: Ut ergo bonum iam suum haberet homo, emancipatum sibi a Deo, et fieret proprietas iam boni in homine et quodammodo natura, de institutione adscripta est illi quasi libripens emancipati a Deo boni libertas et potestas arbitrii, quae efficeret bonum ut proprium iam sponte praestari ab homine, - quoniam hoc et ratio bonitatis exigeret, voluntarie exercendae, ex libertate scilicet arbitrii, non favente institutioni non serviente - ut ita demum bonus consisteret homo, si secundum institutionem quidem, sed ex voluntate iam bonus inveniretur, quasi de proprietate naturae, proinde ut et contra malum - nam et illud utique Deus providebat - ut fortior homo praetenderet, liber scilicet et suae potestatis, quia si careret hoc iure, ut bonum quoque non voluntate obiret sed necessitate, usurpabilis etiam malo futurus esset ex infirmitate servitii, proinde et malo sicut bono famulus. Por. także: J. AleXAndre, Une Chair Pour La Gloire, dz. cyt., s. 169. 


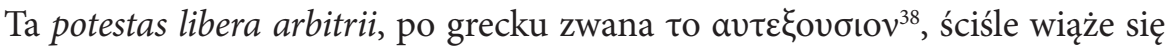
$\mathrm{z}$ naturą i podobnie jak natura, skłaniać może się ku dobremu lub ku złemu. Jest to działanie po linii moralnej, z czego musi rodzić się odpowiedzialność, która spada nie na Boga, jako dawcę wolnej woli, ale na człowieka, jako jej pana i użytkownika ${ }^{39}$.

Bóg szanuje wolną wolę i pozwala korzystać z tego daru, nawet wtedy, gdy człowiek używa go źle ${ }^{40}$. Bóg nie chce grzechu i zła, ale raz udzielonego daru wolności nie cofa i nie ingeruje, gdy człowiek go nadużywa, gdyż jest on jednym z elementów konstytutywnych człowieka. Bóg konsekwentnie dopuszcza zatem, aby człowiek zgodnie z własnym duchem i rozumem używał wolności bez ograniczeń, nawet ze zgubnymi skutkami dla samego siebie ${ }^{41}$. Gdyby Bóg interweniował, przeszkodził w czynieniu zła na mocy swej opatrzności i potęgi czy wiedzy, byłby oskarżony o niestałość $\mathrm{w}$ tym, co sam ustanowi ${ }^{42}$. Człowiek osobiście ponosi winę za grzech i upadek: A więc, jak Bóg wprowadził człowieka do stanu życia, tak człowiek ściagną na siebie stan śmierci, i to nie przez słabość jak i przez nieświadomość, aby tu czegoś nie przypisano Stwórcy. Bo choć ten, co uwiódt, był aniołem, to ten, co został skuszony, był wolnym i panem siebie samego i wyraźniejszym od anioła obrazem i podobieństwem Boga, bo otrzymat tchnienie ducha $w$ materię ${ }^{43}$.

Należy więc zrozumieć, że wina za grzech obciąża duszę ludzką, nie dlatego, że jest ona tchnieniem Boga, ale na skutek niewłaściwego użycia przynależnej jej władzy wolnej woli i wyboru: Przeto można spostrzec, że dusza nie zgrzeszyła $z$ racji tego, co w niej jest pokrewne Bogu, to jest tchnienia, ale $z$ powodu tego, co doszło do jej substancji, czyli wolnego wyboru danego jej przez Boga, oczywiście rozumnie, a przez człowieka użytego niewłaściwie w sposób dobrowolny ${ }^{44}$.

38 Por. De anima 21, 6.

39 Adversus Marcionem II, 6, 1: Sed quoniam ex hoc iam intellegimur eo struentes liberam hominis potestatem arbitrii sui, ut quod ei evenit non Deo, sed ipsi debeat exprobrari, ne et tu hinc iam opponas non ita illum institui debuisse, si libertas et potestas arbitrii exitiosa futura esset, hoc quoque prius defendam ita institui debuisse, quo fortius commendem et ita institutum et digne Deo institutum, potiore ostensa ea causa, quae ita fecit institui.

40 Por. TAMżE, II, 7, 1 .

41 Por. TAMżE, II, 7, 2 .

42 Por. TAmżE, II, 7, 4. W polemice z Marcjonem Tertulian udowadnia, że taka postawa Boga jest wyrazem Jego dobroci; na temat dobroci Boga w relacji do Jego wolności por. S. STRĘKOWSKI, Wolność Boga według Tertuliana. Uwagi literackie, ST 16 (1998), s. 194; por. też: S.A. PANIMOLLE, Dio Padre negli scritti di Tertulliano, DSBP 1, s. 250-251; T.G. RING, Auctoritas bei Tertullian, Cyprian, und Ambrosius, Würzburg 1975, s. 58-60.

43 Adversus Marcionem II, 8, 2: Igitur sicut Deus homini vitae statum induxit, ita homo sibi mortis statum adtraxit, et hoc non per infirmitatem, sicuti nec per ignorantiam, ne quid auctori imputaretur. Nam etsi angelus qui seduxit, sed liber et suae potestatis qui seductus est, sed imago et similitudo Dei fortior angelo, sed adflatus Dei generosior spiritu materiali, quo angeli constiterunt. (tłum. PSP 58, s. 78).

44 TAMżE, II, 9, 8: Itaque non per illud iam videri potest anima deliquisse, quod illi cum Deo adfine est, id est per adflatum, sed per illud, quod substantiae accessit, id est per liberum arbitrium, a Deo quidem rationaliter adtributum, ab homine vero qua voluit agitatum. (tłum. PSP 58, s. 80). Por. także: J. Alexandre, Une Chair Pour La Gloire, dz. cyt., s. 171-172. 
Wolność, która jednak poprzez wybory prowadzi do zła, jest wolnością chorą i skarłowaciałą; aby wybierać dobrze, potrzeba woli dojrzałej, która potrafi dostrzec dobro i zaangażować się w służbę dobra ${ }^{45}$. Wymaga to umiejętności wyboru wartości wyższych od niższych i systemu np. prawa, który te wartości wskazuje. Takie prawo daje Bóg. Człowiek, gdyby nie posiadał wolnej woli i możliwości dokonywania wyboru, nie otrzymałby od Boga żadnych przepisów prawnych i przykazań. Podobnie, Bóg by nie upominał, nie karcił i nie pouczał, gdyby człowiek nie ponosił odpowiedzialności za własne czyny, to znaczy dokonywane wybory i okazywaną wzgardę lub posłuszeństwo wobec Bożego prawa. Bóg nie nakładałby też żadnej sankcji na człowieka i zagrożenia śmiercią za popełnione wykroczenia ${ }^{46}$.

Chrześcijaństwo wnosiło w świat starożytny całkowicie nowe spojrzenie na wiele spraw. Tak było też w kwestii rozumienia woli i ludzkiej wolności. Różnicę między tymi dwiema koncepcjami trafnie ukazuje M. Pohlenz, którego wypowiedź warto przytoczyć: „Wolność rozumiana po grecku jest samo-determinacją człowieka naturalnego; wolność w ujęciu Pawła jest wyzwoleniem spod władzy grzechu, dokonanym przez Boga, jest odkupieniem. Pojęcie odkupienia jest całkowicie obce Grekom. Mieli oni misteria, które pozwalały wtajemniczonemu spodziewać się szczęśliwego losu po śmierci, ale nie oznaczało to odkupienia od winy. Istniały także sekty, które wierzyły w metempsychozę i za cel stawiały sobie odkupienie od ziemskich zbałamuceń; ale jego urzeczywistnienie było dziełem człowieka. Idea zbawiciela wysłanego przez Boga, który mógłby odkupić od grzechu, była im całkowicie obca, nie mniej obca niż stan ducha Pawła, który czuł wzdychanie stworzenia oczekującego na odkupienie (Rz 8, 22). Dla Pawła właśnie idea odkupienia jest niezwykłą wiadomością, którą szerzy on jako dobrą nowinę. To nie ze świata greckiego mógł zaczerpnąć inspirację [...]" ${ }^{\prime 7}$.

Na tle powyższej wypowiedzi widać wyraźniej, jak Tertulian wpisuje się $\mathrm{w}$ tworzenie nowego rozumienia wolnej woli człowieka. Chociaż posługiwał się terminem liberum arbitrium, wola nie była dla niego jedynie funkcją rozumu prowadzącą do podjęcia lub zaniechania konkretnego działania. Owszem, przejawia się ona w podejmowaniu decyzji i zadań, z wszelkimi tego konsekwencjami w rodzącej się przy tym odpowiedzialności, ale jest ukazana jako odrębna władza

45 Por. J. Galarowicz, Na ścieżkach prawdy, dz. cyt., s. 546.

46 Por. Adversus Marcionem II, 5, 7: Non enim poneretur lex ei, qui non haberet obsequium debitum legi in sua potestate, nec rursus comminatio mortis transgressioni adscriberetur, si non et contemptus legis in arbitrii libertatem homini deputaretur. Sic et in posteris legibus creatoris invenias, proponentis ante hominem bonum et malum, vitam et mortem, sed nec alias totum ordinem disciplinae per praecepta dispositum a vocante Deo, et minante et hortante, nisi et ad obsequium et ad contemptum libero et voluntario homini. Por. Pwt 30, 15.19.

47 M. Pohlenz, La libertà greca, Brescia 1963, s. 230 n.; cyt. za: G. ReAle, Historia filozofii starożytnej, dz. cyt., t. V, s. 256-257. 
duszy ludzkiej. Nie jest jakąś przypadłością, ale zostaje wpisana w naturę duszy, a więc stanowi też o istocie duszy pochodzącej od samego Boga.

\section{Odpowiedzialność za zło czyli kwestia nagrody i kary}

Wolna wola domaga się odpowiedzialności za zło i dobro oraz nagrody i kary dla człowieka za dokonane wybory i czyny. W Adversus Marcionem Tertulian zwraca uwage, że: Zresztą ani zapłaty za dobro, ani kary za zło nie można by wypłacać stusznie i sprawiedliwie człowiekowi, który by się okazał dobrym lub złym $z$ konieczności, a nie wolnej woli. A i Prawo ustanowione zostało na to, by nie wykluczało wolności, lecz ja aprobowało przez nagrodę za posłuszeństwo okazywane mu dobrowolnie lub przez kare za przekroczenie go z własnej woli. Tak w obydwu skutkach ujawniła się wolność wyboru ${ }^{48}$.

Nie należy zatem Boga oskarżać za to co się dzieje, ale ludzkie wybory. Człowiek jako stworzenie Boże, obdarzony wolną wolą i władzą nad sobą, może też odnieść zwycięstwo nad złem i szatanem przez zachowanie Bożego prawa. Bóg nie nakładałby tego prawa, nie zagroziłby wyrokiem śmierci, ani nie obdarzyłby człowieka wolną wolą, gdyby ten faktycznie był zbyt słaby ${ }^{49}$; właściwe użycie wolnej woli przynosi człowiekowi zwycięstwo:

Odłożył bowiem walkę [Bóg], aby i człowiek za pomocą tej samej wolności woli, która mu przypadła, utrącił wroga, dając dowód swojej, a nie Boga winy, i tak aby z godnością odzyskał zbawienie drogą zwycięstwa ${ }^{50}$.

Tertulian nie zatrzymuje się na wymiarach metafizycznych bytu ludzkiego, ale mówiąc o wolnej woli i wolności osobistej człowieka przenosi akcent na konkretne działania. Dlatego też, jak zaznacza S. Strękowski, „w wyrażeniu «secundum imaginem et similitudinem fieri» należy widzieć działanie ludzkie jako realizację zadań wolnej woli, a przez to nabiera ono cech działania niezależnego i suwerennego i przez to naśladuje Boga, ponieważ Jego działanie jest w pełni suwerenne" ${ }^{\text {51 }}$. Jednocześnie Bóg, ponieważ jest wszechmocny i wolny, może nadać prawo

${ }_{48}$ Adversus Marcionem II, 6, 7: Ceterum nec boni nec mali merces iure pensaretur ei, qui aut bonus aut malus necessitate fuisset inventus, non voluntate. In hoc et lex constituta est, non excludens, sed probans libertatem de obsequio sponte praestando vel transgressione sponte committenda: ita in utrumque exitum libertas patuit arbitrii. (tłum. PSP 58, s. 76).

49 Por. Adversus Marcionem II, 8, 3: Atque adeo eundem hominem, eandem substantiam animae, eundem Adae statum eadem arbitrii libertas et potestas victorem efficit hodie de eodem diabolo, cum secundum obsequium legum Dei administratur.

50 TAMżE, II, 10, 6: Certamini enim dedit spatium, ut et homo eadem arbitrii libertate elideret inimicum, qua succiderat illi, probans suam, non Dei culpam, et ita salutem digne per victoriam recuperaret, et diabolus amarius puniretur ab eo, quem eliserat ante, devictus. (tłum. PSP 58, s. 81).

51 S. STRĘKOWSKI, Wolność osobista człowieka według Tertuliana, art. cyt., s. 178; por. Tertuliano, La testimonianza dell'anima, Introduzione, traduzione e note di P.A. Gramaglia, Roma 1982, s. 199. 
i zaproponować swoją wolę zbawczą w sposób prawomocny temu wszystkiemu, co do Niego należy $y^{52}$. Doskonały, wszechmocny i wolny Bóg może pragnąć tylko dobra stworzeń, dlatego Jego wola wychodzi na spotkanie wolności człowieka, nie przekreśla jej, ale ją uszlachetnia i wywyższa, i pomaga człowiekowi dobrze z niej korzystać na drodze uświęcenia i zbawienia ${ }^{53}$.

Tertulian niejednokrotnie w swych pismach zwraca uwagę w jak wielkim błędzie są ci wszyscy, którzy przyjmują jedynie Boga Nowego Testamentu i sądzą, że w swej łagodności i dobroci, nie będzie karał za zło. Jaki więc byłby sens ustanawiania przykazań bez konieczności ich zachowywania i bez zamiaru karania za nieposłuszeństwo?

Jeżeli jest rzecza niegodna, aby Bóg sądził, albo jeżeli pod tym warunkiem jest to godne, aby Bóg sadzit, że nie chce i zabrania, ale nie karze już dopuszczonego przestępstwa, to trzeba powiedzieć, że nic nie jest tak niegodne Boga, jak nie wymagać, czego nie chciał i zabraniać dopuszczania się tego. Po pierwsze dlatego, że winien jest dla jakiegokolwiek postanowienia swojego i dla prawa ustanowić karę na potwierdzenie swojego autorytetu $i$ konieczności posłuszeństwa, po drugie dlatego, że do dobrego obrońcy należy i to $z$ konieczności, aby nie chciat dopuścić do przestępstw, a nie chcąc ich zakazat. Natomiast być pobłażliwym dla zła, to jest dla Boga bardzo niegodne, niż by je spostrzegał, a tym bardziej dla Boga najlepszego, który jest dobrym nie w innym znaczeniu, jak będąc przeciwnikiem zła. Bo miłość do dobra ujawnia się w nienawiści do zła, a ochronę dobra wypełnia zwalczaniem $z \nmid a^{54}$.

Gnostycy stali na stanowisku, że Bóg osądza zło właśnie przez to, że go nie chce i zarazem potępia je, kiedy go zabrania. Jednocześnie Bóg wybacza zło przez to, że go nie potępia i uwalnia od niego, ponieważ go nie karze ${ }^{55}$. Tertulian piętnuje błędne przekonanie Marcjona o Bogu wyższym i lepszym od karzącego Stwórcy. Wskazuje na fałsz i zakłamanie takiego stanowiska. Jak Bóg mógłby bać się potępić to, co potępia i lękać się nienawidzić to, czego nie kocha? Złudna jest taka dobroć i pozorna karność, jeśli Bóg nie chciałby pokochać tego, czego nie chce uznać i zezwalałby na fakt, na który nie zezwala, aby się sta5 ${ }^{56}$. Tertulian konkludując ironizuje, że skoro odnaleziono Boga, który jest lepszy, nie obraża się, nie gniewa i nie karze, to nie pozostaje nic innego, jak tylko grzeszyćc ${ }^{57}$ : I do tego stopnia wyróżniaja się Marcjonici, że w ogóle nie boja się swojego Boga. Złego bowiem, jak mówią, będa się bać, dobrego zaś miłować. Głupcze dlaczego

52 Por. A. Solignac, La liberté chez les Peres de L'Église, DS 9, kol. 812.

53 Por. S. StręKowski, Wolność Boga wedtug Tertuliana, dz. cyt., s. 198.

54 Adversus Marcionem I, 26, 5 (tłum. PSP 58, s. 63).

55 Por. Ireneus, Adversus haereses, I, 27, 3; w źródłach gnostyckich: Hipostaza archontów, Nag Hammadi Codex II, p. 90, 19- 91, 14, Świadectwo prawdy, Codex IX, p. 47, 10 -48, 15: dotyczy stwórcy, demiurga, nie Boga; za: PSP 58, s. 63, przyp. 143.

56 Por. Adversus Marcionem I, 27, 1 (tłum. PSP 58, s. 64).

57 Por. tamże, I, 27, 2.5. 
nazywasz go panem, a twierdzisz, że nie należy się go bać, skoro ta nazwa jest właściwościa potęgi, której należy się bać? A w jaki sposób będziesz go miłować, jeżeli nie będziesz się obawiał braku miłości? Oczywiście, że nie jest on ani twoim ojcem, któremu należy się i miłość z powodu ojcowskiego oddania, i bojaźń z powodu ojcowskiej władzy. Nie jest też dla ciebie panem prawomocnym, abyś go miłował $z$ powodu ludzkiego zachowania, a bał się go z powodu karności. ${ }^{58}$

Kara za uczynione zło wydaje się czymś logicznym. Sąd nad grzesznikami marcjonici przypisywali więc Stwórcy, nie Bogu Najwyższemu; uważali, że grzesznicy będą odrzuceni, utracą zbawienie i pochłonie ich ogień Stwórcy. Tertulian wykazuje jednak, że nie ma takiego Boga. Idea Boga w ujęciu Marcjona jest całkowicie wypaczona, bo jak może odpuszczać grzechy, ktoś, kto ich nie pamięta, kto ich nie osądza i jak może uwalniać od śmierci ten, kto jej nie zwyciężył ${ }^{59}$.

Kwestia nagrody i kary za życie człowieka na ziemi oraz sprawa odpokutowania za popełnione zło była dla wielu głównym argumentem za przyjęciem nauki o wędrówce dusz i reinkarnacji. Tertulian podejmuje te zagadnienia w $D e$ anima. Zauważa, że stosownie do zasług i win, dla każdej z dusz przypisuje się inny rodzaj zwierzęcia: bądź to zwierzęta przeznaczone na zhańbienie i zabicie, czy też do ciężkiej pracy - dla dusz skazanych na pokutę; lub zwierzęta najpiękniejsze, najlepsze i pożyteczne - dla dusz idących po nagrodę ${ }^{60}$. Ponieważ natura i cechy zwierząt są odmienne od ludzkich i dusza przyjmując je musiałaby się zmienić, zatem nie byłaby już tą samą. W konsekwencji więc, jak udowadnia Kartagińczyk, nagrody i kary dostępowałyby zupełnie inne dusze, niż te, które na nie zasłużyły, a zatem i teoria reinkarnacji mija się z celem ${ }^{61}$. Zwolennicy metempsychozy, jak zaznacza Menghi, nie wyrażają się w prawdzie jasno, czy dusza, która raz weszła w ciało zwierzęcia pozostaje ta sama, czy też przyjmuje cechy danego zwierzęcia ${ }^{62}$. Waszink wyjaśnia jednak, że to ta pierwsza teza jest $\mathrm{z}$ reguły poświadczona w starożytnych tekstach, także dlatego, że metempsychoza była zazwyczaj uważana za formę kary i zadośćuczynienia ${ }^{63}$.

Kolejny argument, jaki Tertulian przytacza przeciw reinkarnacji, to nieadekwatność nagród i kar w ciałach zwierząt. Często osąd ludzki jest zbyt surowy w nakładaniu kar i zbyt łaskaw w darowaniu. Przypisywanie poszczególnym duszom za konkretne czyny losu konkretnych zwierząt jest całkowicie błędne. Niejednokrotnie bowiem najgorszy

\footnotetext{
58 Por. Adversus Marcionem I, 27, 3 (tłum. PSP 58, s. 64).

59 Por. tamże, I, 28, 1-2.

60 Por. De anima 33, 1, CCL 2, s. 832.

61 Por. TAMżE: et hic dicam: si demutantur, non ipsae dispungentur quae merebuntur.

62 Por. Tertulliano, L’anima, a cura di M. Menghi, dz. cyt., s. 241, przypis 256.

63 Por. Tertullianus, De anima, edited with introduction and commentary by J.H. Waszink, dz. cyt., s. 390; Homerus, Odissea 10, 240; w: L’Odyssée, Poésie Homérique, texte établi et trad. par V. Bérard, t. 2, Paris 1947, s. 65; Ovidius, Metamorphoses II, 485; w: Ovid, Metamorphoses, with an English translation by F.J. Miller, t. 1, Cambridge - Massachusetts - London 1946, s. 94.
} 
los zwierząt jest lżejszy od losu ludzi - jakaż zatem odpłata za najcięższe zbrodnie? podobnie jak najlepszy żywot zwierząt nie może się równać z żadną nagrodą nawet doczesną ${ }^{64}$. Dlatego Tertulian wskazuje, że zakładając reinkarnację, kara może w istocie okazać się ulgą dla duszy, natomiast nagroda jej obciążeniem: Jakie zwierze przypisać nieskażonej niewieście Dydonie? Jakiego ptaka przydzielić cierpliwości, jakiż rodzaj zwierzęcia świętości, jaką̇̇ rybę niewinności? Wszystkie te zwierzęta są w stużbie człowieka, wszystkie podlegte, wszystkie dane na własność. Jeżeli człowiek zostanie którymś z nich, będzie poniżony [...] Co za sądy boskie tak zwodnicze po śmierci człowieka, lekceważące $w$ karaniu, wybredne w okazywaniu łaskawości, których ani najgorsi się nie boją, ani najlepsi nie pragna, do których raczej podążaja zbrodniarze niż święci. Jedni dlatego, że szybciej uszliby doczesnej sprawiedliwości, drudzy później by jej doznalín ${ }^{65}$.

Odpłata u kresu ludzkiego życia powinna być pełna i doskonała. Jak wskazuje Tertulian, reinkarnacja wcale jej nie zapewnia. Jedynie prawdziwy osąd wyda Bóg: Bóg zatem będzie sądzit najpetniej, ponieważ ostatecznie, przez wieczny wyrok tak kary, jak ulgi (nagrody); przez powrót dusz nie w zwierzęta lecz we własne ciała i to jeden raz i w owym dniu, który zna jedynie Ojciec; aby dusza, trwając $w$ oczekiwaniu, doświadczała się $w$ trosce (niepokoju) wiary, wypatrując $w$ codziennej obawie i w codziennej nadziei owego dnia, którego nie zna ${ }^{66}$.

Losy duszy po śmierci stają się specyficznym tematem w polemice teologicznej przeciwko gnostykom. Począwszy od II wieku pisarze kościelni próbują zgłębiać teksty biblijne o znaczeniu eschatologicznym. Pismo święte ukazuje wprawdzie istnienie szczęścia trwałego aż do końca czasów, ale nie przedstawia wyraźnych opisów na temat losów duszy ludzkiej po śmierci, w okresie pomiędzy wniebowstąpieniem Chrystusa a paruzją - Jego ponownym przyjściem w chwale przy końcu czasów ${ }^{67}$. Gnostycyzm opowiadał się za bezpośrednią wizją Boga zaraz po śmierci i tu był niezgodny z ortodoksją, która oddalała ostateczną odpłatę na czas po zmartwychwstaniu $^{68}$. Chrześcijaństwo pierwotne uzależniało los poszczególnego człowieka od całej historii zbawienia, ukazując, że nie jest rzeczą możliwą izolować zmartwychwstanie

64 Por. De anima 33, 2-10.

65 De anima 33, 9-10: quam bestiam integrae feminae Didoni? quam volucrem patientia, quam pecudem sanctimonia, quem piscem innocentia sortientur? omnia famula sunt hominis, omnia subiecta, omnia mancipata. Si quid horum futurus est, diminoratur illic ille [...]

O iudicia divina post mortem humanis mendaciora, contemptibilia de poenis, fastidibilia de gratiis, quae nec pessimi metuant nec optimi cupiant, ad quae magis scelesti quam sancti quique properabunt, illi, ut iustitiam saeculi citius evadant, isti, ut tardius eam capiant!

${ }_{66}$ De anima 33, 11: Deus itaque iudicabit plenius, quia extremius, per sententiam aeternam tam supplicii quam refrigerii nec in bestias, sed in sua corpora revertentibus animabus, et hoc semel et in eum diem quem solus pater novit, ut pendula expectatione sollicitudo fidei probetur, semper diem observans, dum semper ignorat, cotidie timens, quod cotidie sperat.

67 Por. C. Tibiletti, Le anime dopo la morte: Stato intermedio o visione di Dio?, „Augustinianum” 28 (1988), s. 631.

68 Por. De resurrectione mortuorum 58, 1: nihil aeternum nisi post resurrectionem. 
jednostek od wydarzenia zbawczego w jego całości. W centrum wydarzenia zbawczego należy bowiem umieszczać wypełnienie się całej historii zbawienia, a nie los jednostki. Po grzechu pierworodnym, jego skutki i przekleństwo śmierci przeszły na całe stworzenie ${ }^{69}$, które również „zostanie wyzwolone z niewoli zepsucia, by uczestniczyć w wolności i chwale dzieci Bożych"70. Zmartwychwstanie poszczególnych ludzi może dokonać się zatem tylko w kontekście wyzwolenia całego stworzenia. Pełny udział w Królestwie Bożym wiąże się ze zmartwychwstaniem cielesnym, które nastąpi w określonym momencie czasu całościowo ujmowanej historii zbawienia ${ }^{71}$. Apokatastaza i odnowienie ludzkości dokona się przy końcu dziejów, a nie co jakiś czas, przy śmierci każdego człowieka indywidualnie. W tym momencie, jak słusznie zaznacza C. Tibiletti, należałoby mówić o stanie pośrednim, albo o tym stanie, w którym znajdują się dusze po śmierci aż do zmartwychwstania w ciele ${ }^{72}$. Zmarli należą jeszcze do stanu obecnej historii zbawienia, która wypełni się przy paruzji, wraz z powtórnym przyjściem Chrystusa. Jeżeli po śmierci dusze od razu uczestniczyłyby w pełni życia wiecznego, historia zbawienia kończyłaby się fragmentarycznie, stopniowo i osobno dla każdej jednostki czy też duszy. Ciało tymczasem wraz ze stworzeniem musiałoby czekać końca czasów ${ }^{73}$. Pismo św. przedstawia jednak udział w pełni życia wiecznego dopiero po zmartwychwstaniu i po sądzie ostatecznym ${ }^{74}$.

Gnostycy, którzy pod wpływem platonizmu ciało uważali za wroga duszy, a prawdziwą naturę człowieka identyfikowali z jego duszą, uznawali, że dusze bezpośrednio po śmierci będą przyjęte do nieba i uwolnione od ciężaru ciała od razu ujrzą Boga takim, jakim jest ${ }^{75}$. Wielu pisarzy Kościoła w pierwszych wiekach przyjmując istnienie stanu pośredniego, nie uznawało bezpośredniej wizji Boga od razu po śmierci człowieka.

W De resurrectione mortuorum już na początku Tertulian przedstawia dwie powszechne wówczas teorie dotyczące losów ludzi po śmierci. Pierwsza podkreślała, że nic nie może żyć po śmierci i wraz z nią wszystko się kończy. Druga zakładała, że w człowieku są dwie substancje, dusza i ciało, ale jedynie dusza może mieć jakąś możliwość i formę przeżycia ${ }^{76}$. Chrześcijaństwo przyjmując zbawienie całego człowieka, głosiło również zmartwychwstanie ciała. Dla gnostyków sięgających do myśli orfickiej czy też pitagorejsko-platońskiej, ciało jawiło się jako przeszkoda do zbawienia. Tym co istotne był sam intelekt bez ciała. Człowiek bezcielesny zatem, to człowiek gnostycki i jego zmartwychwstanie nie jest niczym 
innym, jak tylko aktem inteligencji, świadomości, w której dochodzi do uznania samego siebie w momencie, kiedy intelekt oczyszczony z wszelkiego kontaktu $\mathrm{z}$ ciałem spotyka się z intelektem powszechnym człowieka przebóstwionego ${ }^{77}$.

Przystępując w De anima do omawiania pośmiertnych losów duszy, Tertulian czyni ogólne odniesienie do podstawowych kierunków filozoficznych: Niemal wszyscy filozofowie, którzy jakkolwiek pojmuja, jednak popieraja nieśmiertelność duszy, jak Pitagoras, Empedokles, Platon, i ci, którzy przyznaja jej pewien czas trwania po odejściu [z ciała] aż do powszechnego spalenia, umiejscawiaja jak stoicy jedynie swoje dusze, to jest dusze mędrców w wyższych sferach ${ }^{78}$. Platon wprawdzie nie przedstawia takiego układu wyłącznie co do dusz wszystkich filozofów, lecz tych, którzy uczcili filozofię przez ich miłość do chłopców w9. Oto jak wielka wage przywiązuja filozofowie także do nieczystości. Tak więc u Platona dusze mądrych unosza się do eteru ${ }^{80}$, u Ariusza w powietrze $e^{81}$, u stoików pod księżyc ${ }^{82}$.

Kartagiński autor nie wdaje się w wyjaśnianie i polemikę co do szczegółowego pojmowania nieśmiertelności duszy i form, czy miejsca jej bytowania po śmierci według różnych teorii filozoficznych. Wyraża jedynie zdziwienie odnośnie do logiczności umiejscawiania dusz ludzi uczonych w górze, niewykształconych w pobliżu ziemi, a wszelkich pozostałych w piekle wewnątrz ziemi, gdzie jest wszelka nieczystość i sromota, jak opisywał to Platon w Fedonie ${ }^{83}$.

Opierając się na nauce św. Pawła (Kol 1, 2; Ga 5, 5; Flp 3, 12), Tertulian przyjmował podwójne zmartwychwstanie duszy: zmartwychwstanie duchowe (prima resurrectio) i zmartwychwstanie cielesne (secunda resurrectio) ${ }^{84}$. Zmartwychwstanie

77 Por. E. Peterson, L’uomo disincarnato, w: Umanesimo e mondo cristiano, Roma 1951, s. 115; P. Siniscalco, Ricerche sul «De resurrectione» di Tertulliano, dz. cyt., s. 113.

78 Por. AËTIOs 4, 7, 1; SVF 1, 522. Idea powszechnego pożaru, który wszystko niszczy, a świat każdorazowo odradza się w identycznych formach znana była w doktrynie stoickiej.

79 Tertulian czyni tu aluzję do Fajdrosa 249 A.

80 Por. Fajdros 249 A.

81 Ariusz (Arejos Didymos) - nauczyciel cesarza Augusta, streścił poglądy stoików w dziele, którego fragmenty zachowali Stobajos i Euzebiusz z Cezarei; por. Euzebius, Praeparatio evangelica $15,20,4$, PG 21, 1349.

82 Por. De anima 54, 1-2: Omnes ferme philosophi, qui immortalitatem animae, qualiterqualiter volunt, tamen vindicant, ut Pythagoras, ut Empedokles, ut Plato, quique aliquod illi tempus indulgent ab excessu usque in conflagrationem universitatis, ut stoici, suas solas, id est sapientium, animas in supernis mansionibus collocant. Plato quidem non temere philosophorum animabus hoc praestat, sed eorum qui philosophiam scilicet exornaverint amore puerorum. Adeo etiam inter philosophos magnum habet privilegium impuritas. Itaque apud illum in aetherem sublimantur animae sapientes, apud Arium in aerem, apud stoicos sub lunam.

83 Por. Plato, Phaedo 111 E - 112 A, dz. cyt., s. 382.

84 Por. G. BARDy, Résurrection, Dictionnaire de Théologie Catholique 13, 2524. Tertulian wyjaśnia, że w ścisłym słowa znaczeniu zmartwychwstanie może dotyczyć właściwie ciała, gdyż powstać może tylko to, co wcześniej upadło i powstać z martwych może tylko to, co wcześniej umarło, dusza natomiast w swej istocie jest nieśmiertelna (por. np. De resurrectione mortuorum 18, 4-9; Adversus Marcionem V, 9, 4). Z tego względu Kartagiński pisarz często używał określeń: carnis resuscitator, 
duchowe następuje zaraz po śmierci, w różnym czasie dla każdego człowieka i polega na zniszczeniu wszelkiego grzechu człowieka oraz zakorzenieniu się w Chrystusie ${ }^{85}$. Przy końcu świata dokona się natomiast zmartwychwstanie cielesne, w tym samym i realnym ciele, $w$ jakim człowiek żył na ziemi ${ }^{86}$. Wówczas nastąpi sąd ostateczny nad wszystkimi ludźmi i zapadną ostateczne wyroki ${ }^{87}$. W tym nauczaniu Tertuliana można dostrzec elementy millenaryzmu, przy jednoczesnej krytyce alegorycznej interpretacji eschatologicznych tekstów biblijnych u montanistów i z podkreśleniem realizmu zmartwychwstania oraz lokalizacją nowego Jeruzalem w Palestynie ${ }^{88}$.

Tertulian przyjmował dwustopniowość zarówno szczęścia, jak też potępienia w życiu przyszłym, mianowicie zaraz po śmierci w wymiarze czasowym w otchłani i po zmartwychwstaniu ciał w wymiarze wiecznym. Wskazuje na to użycie odpowiedniej terminologii. Mówiąc o czasowym szczęściu dusz po śmierci, obok wyrażenia „miejsce wytchnienia” (refrigerium) Tertulian używał takich określeń jak: tymczasem (interim), w otchłani (apud (penes) inferos), na łonie Abrahama (in sinu Abraham), które wskazują na czasowość tego stanu. Kiedy mówił o szczęściu wiecznym zbawionych, refrigerium określał jako: aeternum, sempiternum, czyli wieczne. Podobnie dusze potępionych po śmierci otrzymują czasową karę w otchłani, a po sądzie ostatecznym idą na wieczne potępienie (w dzisiejszej terminologii do piekła). Mówiąc o karze po śmierci Kartagińczyk stosował określenia: męka (cruciatus), zguba, zagłada (exitium), piekło (gehenna), ogień (ignis), kara (poena), zatrata, katusze (supplicium), męczarnie (tormentum); odpowiednio dodając przymiotnik: wieczny, ustawiczny, wiecznotrwały (aeternus, perpetuus, sempiternus) ${ }^{89}$.

carnem resuscitsre, resurget caro, corporalis resurrectio, corporaliter resurgere, carnis redintegratio, por. R. Braun, «Deus Christianorum», dz. cyt., s. 530n.; P. SinisCalco, Ricerche sul «De resurrectione» di Tertulliano, dz. cyt., s. 101-103. Poganie i gnostycy uważali, że element zmysłowy i widoczny w człowieku jest w zupełności niegodny, by uczestniczyć w zbawieniu, dlatego Tertulian podejmował z nimi polemikę, wykazując, że jedynie formalnie i powierzchownie zgadzają się z chrześcijaństwem ci, którzy uczą jedynie o zbawieniu duszy i tylko o zmartwychwstaniu duchowym, co najwyżej ciała duchowego; por. P. SinisCalCo, Ricerche sul «De resurrectione» di Tertulliano, dz. cyt., s. 104.

85 Por. De resurrectione mortuorum 23-32; J. TuRMel, Tertullien, dz. cyt., s. 273-275; J. DANiÉLou, Les orígines du christianisme latin, dz. cyt., 312-315.

${ }^{86} \mathrm{Na}$ temat integralności i identyczności substancji ciała zmartwychwstałego w ujęciu Tertuliana por. P. Siniscalco, Ricerche sul «De resurrectione» di Tertulliano, dz. cyt., s., 154-167.

87 Por. De resurrectione mortuorum 35-37.

88 Por. Adversus Marcionem III, 24, 3: Nam et confitemur in terra nobis regnum promissum, sed ante caelum, sed alio statu, utpote post resurrectionem in mille annos in civitate divini operis Hierusalem caelo delatum, quam et apostolus matrem nostram sursum designat. K. Obrycki wskazuje, że chodzi tu o millenaryzm duchowy, por. PSP 58, s. 137, przypis 237; por. także: J. DANiÉLou, Les orígines du christianisme latin, dz. cyt., s. 126-128.

89 Por. K. Оввускі, Los złych po śmierci według Tertuliana, VoxP 10 (1990) z. 19, s. 602-603; szerzej: Tenże, Refrigerium u Tertuliana, w: TeRtulian, Wybór pism, II, PSP 29, Warszawa 1983, s. 34-42; użycie omawianej terminologii patrz odpowiednie hasło w: G. ClaEsson, Index Tertullianeus, Paris 1975, t. 1-3. 
Tertulian stał na stanowisku, że po śmierci wszystkie dusze dostają się do otchłani i tam oczekują Dnia Pańskiego. Otchłań jest więc miejscem, do którego dostają się zarówno dobrzy jak i źli, tam zajmując odpowiednią dla siebie przestrzeń i w zależności od tego, czy dobrze, czy źle postępowali na ziemi ${ }^{90}$, doznają nagrody lub kary: Czy chce się tego, czy też nie, tam właśnie jest miejsce kary (supplicia) i nagrody (refrigeria): przebywa tu ubogi, jak też bogaty ${ }^{91}$.

Tertulian jest zdecydowanym obrońcą teorii o przebywaniu wszystkich dusz w otchłani aż do dnia Sądu ostatecznego. Skoro sam Chrystus Bóg-Człowiek zstąpił do otchłani i przebywał we wnętrznościach ziemi, tym bardziej ten sam los czeka ludzi, którzy są jedynie sługami Pana i nie są nad swego Mistrza. Byłoby wyrazem ogromnej pychy twierdzić inaczej i odrzucać możliwość odbierania pociechy na łonie Abrahama w oczekiwaniu na zmartwychwstanie ${ }^{92}$. Wszystkie dusze są zatem godne przebywania w otchłani. Pojawiały się argumenty, iż Chrystus dlatego zstąpił do otchłani, aby wierni tam nie poszli, jak również, że byłoby niesprawiedliwe ustawianie pogan na równi z chrześcijanami i umieszczanie ich po śmierci w tym samym więzieniu. Tertulian wyjaśniał jednak, że nie ma innej możliwości przejścia po nagrodę wieczną w Królestwie niebieskim, jak tylko dopiero przy powtórnym przyjściu Chrystusa, gdy zagrzmi głos trąby i nastanie dzień Sądu oraz powszechne zmartwychwstanie ${ }^{93}$ :

Dla nikogo niebo nie stoi otworem, jak długo ziemia istnieje, by nie powiedzieć, jak długo jest zamknięta. Dopiero za przemiana świata otworza się królestwa niebieskie ${ }^{94}$.

Poglądy te były zbieżne z myślą intelektualistów chrześcijańskich II i III wieku, wystarczy wspomnieć Justyna, Klemensa Aleksandryjskiego, Ireneusza czy Nowacjana ${ }^{95}$. Nasz autor wprowadza jednak pewien nowy element, wyjątek od tej ogólnej reguły, jaki stanowią dusze męczenników, które według niego, od razu po śmierci mają wstęp do raju. Dusze męczenników są więc wyjątkiem. One od razu po śmierci mają otwarty wstęp do raju i dostępują bezpośredniej wizji Boga. Kluczem do Królestwa niebieskiego

90 Por. De anima 55; De resurrectione mortuorum 43; J. TuRMEL, Tertullien, dz. cyt., s. 276-278.

91 De anima 58, 1: Omnis ergo anima penes inferos? inquis. Velis ac nolis, et supplicia iam illic et refrigeria: habes pauperem et divitem; por.: De testimonio animae 4, 1-11; Adversus Marcionem IV, 34, 1-17.

92 Por. De anima 55, 2.

93 Por. 1 Tes 4, 13-17: Nie chcemy, bracia, waszego trwania $w$ niewiedzy co do tych, którzy umierają, abyście się nie smucili jak wszyscy ci, którzy nie mają nadziei. Jeżeli bowiem wierzymy, że Jezus istotnie umarł $i$ zmartwychwstat, to również tych, którzy umarli w Jezusie, Bóg wyprowadzi wraz z Nim. To bowiem głosimy wam jako słowo Pańskie, że my, żywi, pozostawieni na przyjście Pana, nie wyprzedzimy tych, którzy pomarli. Sam bowiem Pan zstapi z nieba na hasło i na głos archanioła, i na dźwięk traby Bożej, a zmarli w Chrystusie powstana pierwsi. Potem my, żywi $i$ pozostawieni, wraz $z$ nimi będziemy porwani w powietrze, na obłoki naprzeciw Pana, $i w$ ten sposób zawsze będziemy $z$ Panem.

94 De anima 55, 3: Nulli patet caelum terra adhuc salva, ne dixerim clausa. Cum transactione enim mundi reserabuntur regna caelorum.

95 Por. Tertulliano, Ĺanima, a cura di M. Menghi, dz. cyt., s. 252, przypis 408. 
staje się krew przelana dla Chrystusa włączająca je w zbawczą mękę Syna Bożego: $\mathrm{Ci}$, którzy doświadczaja nowej śmierci za Boga i nie naturalnej za Chrystusa, sa przyjęci do miejsca odmiennego i szczególnego. Rozpoznaj różnicę, jaka istnieje między śmiercia poganina i wyznawcy, jeżeli w imię Boga umierasz, jak napomina Paraklet, nie w lekkich gorączkach w swoim łóżku, lecz w męczeństwie, jeżeli weźmiesz swój krzyż i będziesz naśladowat Pana, jak On sam polecił. Jedynym kluczem do raju jest twoja krew ${ }^{96}$.

W kwestii tych poglądów Tertulian bliski jest montanizmowi, który akt męczeństwa miał w szczególnym poważaniu. Jak zaznacza jednak K. Obrycki ${ }^{97}$, a na co już wcześniej zwrócił też uwagę G. Bardy ${ }^{98}$, ten raj, w którym znajdują się dusze męczenników, chociaż jest miejscem szczęśliwości, także pozostaje oddzielony od tego nieba, które jest miejscem przebywania Boga i wszystkich zbawionych po zmartwychwstaniu ciała.

Jeśli chodzi o dusze sprawiedliwych, w otchłani zajmują one miejsce zwane łonem Abrahama i tam pozostają do momentu sądu ostatecznego ${ }^{99}$.

Taka właśnie część nazwij łonem Abrahama. Chociaż nie należy ona do nieba, jest jednak wspanialsza od otchłani przez to, że udziela duszom sprawiedliwych czasowego wytchnienia aż do momentu, kiedy wszyscy po zakończeniu świata zmartwychwstana, by otrzymać pełnię swojej zapłaty ${ }^{100}$.

Miejsce to nie jest zatem niebem, ale miejscem czasowego wytchnienia, które Tertulian inaczej określa terminem refrigerium ${ }^{101}$. Na mocy duchowego zmartwychwstania (prima resurrectio) dusze sprawiedliwych zostają włączone do wspólnoty z Bogiem przez oczyszczenie się z wszelkiej zmazy grzechów i zespo-

96 De anima 55, 5: Nova mors pro Deo et extraordinaria pro Christo alio et privato excipitur hospitio. Agnosce itaque differentiam ethnici et fidelis in morte, si pro Deo occumbas, ut Paracletus monet, non in mollibus febribus et in lectulis, sed in martyriis, si crucem tuam tollas et sequaris Dominum, ut ipse praecepit. Tota paradisi clavis tuus sanguis est; por.: Scorpiace 12, CCL 2, s. 1092-1094; Adversus Marcionem V, 12; Apologeticum 47.

97 Por. K. ОвRYсKI, Los złych po śmierci według Tertuliana, dz. cyt., s. 600.

98 Por. G. BARDy, I Padri della chiesa di fronte ai problemi posti dall'inferno, w: L'inferno (pr. zbior.), Morcellina 1953, s. 127-128.

99 Por. Adversus Marcionem IV, 34, 10; De idolatria 13, 4, CCL 2, s. 1113.

100 Adversus Marcionem IV, 34, 13: Eam itaque regionem, sinum dice Abrahae, etsi non cealestem, sublimiorem tamen inferis, interim refrigerium praebere animabus iustorum, donec consumatio rerum resurrectionem omnium plenitudine mercedis expugnant [...].

101 Terminu tego Tertulian używał w trzech znaczeniach: 1. orzeźwienie, spokój, pociecha, posiłek (por. np. Apologeticum 39, 16: Quantiscumque sumptibus constet /haec cena/ lucrum est, pietatis nomine facere sumptum, siquidem inopes quosque refrigerio isto iuvamus); 2. miejsce ochłodzenia, wytchnienia po śmierci (por. np. Adversus Marcionem III, 24, 1: Ceterum vester Christus pristinum statum Iudaeis pollicetur ex restitutione terrae et post decursum vitae apud inferos in sinu Abrahae refrigerium.); 3. wieczne szczęście przydzielone przez Boga wyrokiem sądu ostatecznego (por. np. De testimonio animae 4, 1, CCL 1, s. 17: Adfirmamus te /o anima/ manere post vitae dispunctionem et expectare diem iudicii proque meritis aut cruciatui destinari aut refrigerio, utroque sempiterno). Szerzej na ten temat por. K. ОвRускі, Refrigerium u Tertuliana, dz. cyt., s. 30-42. 
lenie się z Chrystusem. Kiedy Chrystus ponownie przyjdzie na sąd ostateczny, przy cielesnym zmartwychwstaniu (resurrectio secunda), dusze te w pełni zjednoczą się z Bogiem na wiecznośćc ${ }^{102}$.

Dusze złych po śmierci, również przechodzą do otchłani, ale zajmują miejsce różne od łona Abrahama. Jest to przestrzeń kary i zadość czynienia Bogu za popełnione zło. Miejsca tego Tertulian bliżej nie określa i nie nadaje mu specjalnej nazwy, ale jest to również miejsce oczekiwania na ostateczny wyrok w dniu sądu ostatecznego i powszechnego zmartwychwstania. Dusze potępionych przy duchowym zmartwychwstaniu (prima resurrectio) od razu otrzymają należną sobie karę. Nie będą mogły już od niej nigdy się uwolnić ani przejść do miejsca ochłody (refrigerium). Przy zmartwychwstaniu ciał (secunda resurrectio), na sądzie ostatecznym kara ta zostanie definitywnie zatwierdzona przez Chrystusa, jako kara wiecznego potępienia ${ }^{103}$.

Pojawiał się problem, czy dusza oddzielona przez śmierć od ciała, może bez niego doznawać nagrody lub kary w otchłani? K. Obrycki zwraca uwagę, że kwestia ta, przysporzyła Tertulianowi nieco trudności ${ }^{104}$. W Apologeticum 48, czy też w De anima 7 możemy najpierw przeczytać, że dusza dopóki nie połączy się z ciałem przy zmartwychwstaniu, nie może niczego odczuwać, ani działać. Później jednak Kartagińczyk, opowiadając się za cielesnością duszy, przyznał jej zdolność odczuwania bólu i radości także w otchłani, ale w stopniu niedoskonałym: Ileż razy dusza sama, bez doznań ciała, jest dręczona przez gniew, złość, wstręt, najczęściej nie zdając sobie z tego sprawy? Ile razy w taki sam sposób kiedy cierpi ciało, dusza szuka dla siebie ukrytej przyjemności i oddala się od przykrego wówczas zwiazku z ciałem? Skłamałbym, gdybym nie przyznał, że dusza sama ma niekiedy zwyczaj cieszyć się i radować z owych cierpień ciała. [...] Dlatego też i w otchłani dusza bez ciała potrafi doświadczać przyjemności i cierpienia, jako że jeśli chce, doznaje cierpienia wewnątrz ciała, które nie cierpi i jeśli chce, raduje się w ciele cierpiącym. Jeżeli tak dzieje się za życia na skutek jej wyboru, tym bardziej dojdzie do tego po śmierci z wyroku Boga ${ }^{105}$.

Ostatecznie Tertulian uznał za niedorzeczność i naiwność odmawianie duszy możności doznawania udręki czy też ulgi w otchłani ${ }^{106}$. Jako przykład zdolności duszy do samodzielnego odbierania odmiennych doznań od ciała, Kartagińczyk

${ }^{102}$ Por. K. Овкускі, Los złych po śmierci według Tertuliana, dz. cyt., s. 607.

${ }_{103}$ Por. De anima 55-58; Adversus Marcionem I, 26; I, 28, 4; II, 11; II, 13; IV, 34; K. OвRYCKI, Los złych po śmierci według Tertuliana, dz. cyt., s. 607.

104 Por. K. OвRYскі, Los złych po śmierci według Tertuliana, dz. cyt., s. 601.

105 De anima 58, 4-5: Quotiens inlaeso corpore anima sola torquetur bile ira taedio plerumque nec sibi noto? Quotiens item corpore afflicto furtivum sibi anima gaudium exquirit et a corporis tunc importuna societate secedit? Mentior, si non de ipsis cruciatibus corporis et gloriari et gaudere sola consuevit. [...] Adeo novit et apud inferos anima et gaudere et dolere sine carne quia et in carne et inlaesa si velit dolet et laesa si velit gaudet. Hoc si ex arbitrio suo in vita, quanto magis ex iudicio Dei post mortem?

106 Por. De resurrectione mortuorum 17. 
przywołuje postawę Mucjusza Scewoli ${ }^{107}$, Zenona ${ }^{108}$ i Cyrusa ${ }^{109}$, w momencie gdy doznawali cierpień fizycznych (De anima 58,5). Dla zobrazowania sytuacji w otchłani przedstawił ewangeliczną przypowieść o bogaczu i Łazarzu, którzy chociaż pozbawieni swoich ciał, jednak odpowiednio doznawali boleści i wytchnienia ${ }^{110}$. W taki oto sposób wykazuje, że dusza skoro jest zdolna do doznań bez udziału ciała, będzie mogła doświadczać nagrody lub kary także w otchłani jeszcze przed zmartwychwstaniem, zanim powtórnie połączy się z ciałem.

Dusza wyposażona przez Boga w rozum i wolną wolę jest odpowiedzialna za czynione zło i grzech, ale także za dobro. Człowiek jednak jest jednością substancjalną duszy i ciała, dlatego udział w nagrodach i karach, chociaż po śmierci czasowo dotyka samej duszy, ostatecznie przynależy całemu człowiekowi, przy powtórnym przyjściu Chrystusa i powszechnym zmartwychwstaniu.

Wypracowana przez Tertuliana koncepcja duszy substancjalnej i cielesnej, pochodzącej od Boga i nieśmiertelnej, rozumnej i wolnej w swym wyborze, miała demaskować i obalać wszelkie heretyckie teorie wyrosłe na bazie gnozy i neoplatonizmu, które w pierwszych wiekach stanowiły poważne zagrożenie dla chrześcijaństwa. W ten sposób Tertulian i jego traktaty dogmatyczno-polemiczne na trwałe wpisały się do dziedzictwa chrześcijańskiej myśli teologicznej.

\title{
The problem of evil in Tertullian's polemic with gnosis
}

\author{
SUMMARY
}

Article presents the views of Tertullian on the causes and origin of evil in the context of his polemic with heretics remaining under the influence of Gnostic thought. The analysis refers to the following treatises of Tertullian: Adversus Hermogenem, Adversus Valentinianos, Against Marcion, De anima, Apologeticum. Subject covers the following points: 1. Introduction. 2. The origin of evil. 3. Free will and choice between good and evil. 4. Responsibility for the evil that is the question of rewards and punishments.

\footnotetext{
${ }_{107}$ Przykład często podawany przez apologetów i pisarzy; por.: Ad nationes 1, 18, 3-4, CCL 1, s. 37; Minucius Felix 37, 3, CSEL 2, s. 52; Lactantius, Divinae institutiones 5, 13, 13, w: LaCtance, Institutions Divines livre V, Introduction, texte critique, traduction par P. Monat, SCh 204, Paris 1973, s. 196; Augustinus, De civitate Dei 4, 20, CCL 47, s. 114; tamże 5, 18, CCL 47, s. 152.

108 Por. Apologeticum 50, 9.

109 Por. Ksenofont, Anabasis 1, 9, 6, w: Xénophon, Anabase, Paris 1930, t. 1, s. 82.

110 Por. De resurrectione mortuorum 17. Łk 16, 19-31.
} 